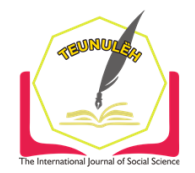

Jurnal Ilmiah Teunuleh

The International Journal of Social Sciences

Vol. 1, Issue. 2, Dec 2020

E-ISSN: 2746-4393

\title{
THE EFFECT OF USING ONLINE MODULE ON THE LEARNING RESULTS OF UT STUDENTS AT THE FINAL EXAMINATION GRADUATION LEVEL
}

\author{
Kuala Ginting ${ }^{1}$ \\ Gemala Widiyarti \\ ${ }^{1}$ Universitas Terbuka, ${ }^{2}$ Universitas Quality \\ ${ }^{1}$ kualaginting@ecampus.ut.ac.id, ${ }^{2}$ widiyartigemala@gmail.com
}

\begin{abstract}
This research was conducted on students of the UPBJJ UT Medan Open University who focused on the PGSD UT students of the Pandan Tapteng Study group. Based on data analysis and research hypothesis testing carried out in Class A and B semester nine UT students registration period 2020.1 it can be concluded as follows: Student learning outcomes using conventional learning in final semester UT students obtained an average value of 71.43. Student learning outcomes using the online module in the final semester students obtained an average value of 80.24 . There is a significant effect of using the online module on UT student learning outcomes at the level of passing the final exam.
\end{abstract}

Keywords: Online Module, Student Learning Outcomes

\section{A. Introduction}

The Open University (UT) as the organizer of PTJJ in Indonesia has students spread across Indonesia with various backgrounds ranging from different and unequal social, economic and infrastructure life. Conditions like this create obstacles in determining the media and learning resources to be used. Therefore, printed teaching materials are still a major component in the teaching and learning process at UT, although some are equipped with multimedia teaching materials, such as: audio, video, or diskettes or compact disks (CDs) containing computer-assisted and internet-based material ( e-learning). The lecture process that takes place at UT, there are several ways, namely online and face to face. Given that the meaning of being open to UT is 
open to all groups, do not know the age and end in what year. This makes the UT learning system more reliant on students.

In the distance learning system teaching materials are the main learning resource for students. UT teaching materials are specifically designed so that students can learn them independently without the help of a tutor. UT teaching materials are printed teaching materials called Basic Materials (BMP). Apart from BMP, printed teaching materials can be in the form of practical manuals and practicum and BMP components. However, considering that Indonesia is a country that is very broad in terms of islands and land, sometimes this becomes an obstacle to the distribution of teaching materials to arrive on time. This also happened in Pokjar Pandan Tapanuli Tengah. Sometimes the distribution of the printed modules that did not arrive on time made the students and tutors a little difficult. However, assisted by the online module, students and tutors can find it easier to carry out the learning process. Moreover, coupled with the increasingly sophisticated communication technology. Students are now using smartphones that can download all applications to support the learning process. There seemed no more reason to make learning difficult. Because with an Internet network, the UT online module can also be opened anywhere.

In fact, even though the UT Pokjar is in the region, the placement for the tutorial location is always located in the City Center so that it is easier for students to reach and of course the extensive Internet network. All academic and administrative services are contained in UT-Online on the website www.ut.ac.id.

Various studies related to UT-Online services have been carried out. Minro

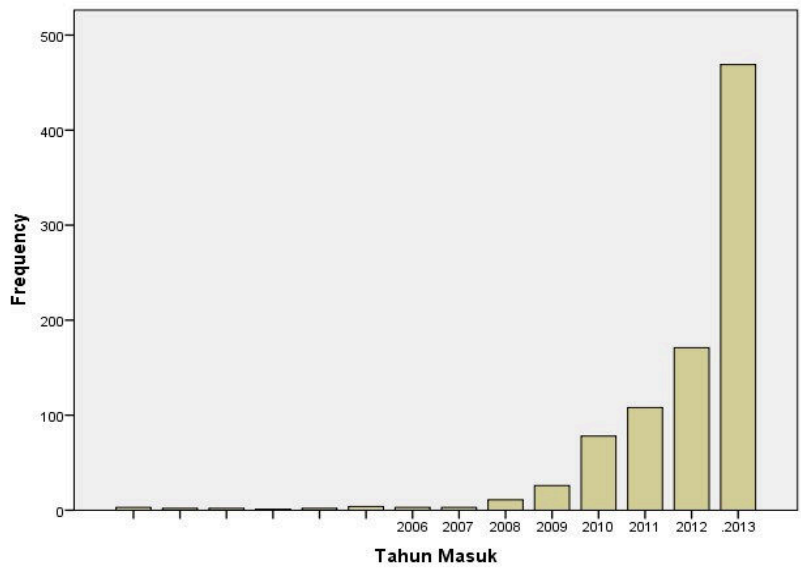

Trends in the number of UT-Online users by year of UT entry Source: S. Sugilar (Jurnal.ut.ac.id) 
The Effect of Using Online Module on the Learning Result of UT Students...

Hayati (2010) examines the aspects of participation in online tutorials and concludes that for each course there are on average 81 students registering, $51.47 \%$ of whom register to activate (login) on online tutorial services. Meanwhile, Royandiah \& Hermawati (2011) who examined the level of participation in online tutorials for the D-2 Library study program reported that the participation rate in tutons was only 2-6\% of the number of registered students. The low level of student activity in online tutorials is explained by Agustina \& Bimo (2010) due to the fact that most students work and have limited time to interact in online tutorials (tuton). Other research leads to student responses to online tutorials conducted by Hendrian (2009).

\section{B. Method}

The design used in this study is the control group pre test post test design shown in table 3.2. This type of research is a quasi-experimental research (quasi-experiment). What is meant by quasi-experiment is that this research will be divided into two groups, namely one experimental class and one control class. This study used a control group research design pre-test-post-test design. One of the experimental groups was treated using the Online module, while the control group was treated with conventional learning.

Table 1 Research Design

\begin{tabular}{|l|c|c|c|}
\hline \multicolumn{1}{|c|}{ Treatment } & Initial Test & Variable & Final Test \\
\hline Online Module & $T_{1}$ & $X_{1}$ & $T_{2}$ \\
\hline Conventional learning & $T_{2}$ & $X_{2}$ & $T_{2}$ \\
\hline
\end{tabular}

Information :

$T_{1}$ : Initial Test

$T_{2} \quad$ : Final Test

$X_{1} \quad$ : Students' abilities using the Online Module Learning Media

$X_{2} \quad$ : Students' abilities using conventional learning

\section{Findings}

\section{Description of Research Data}

Description of the data in this study is learning using online module media and conventional learning on the learning outcomes of UT students at the passing level of 
the Pokjar Tapteng-Pandan final exam. The learning outcome data will be used as a reference for which one is better taught, using online module media taught by conventional learning.

1. Data Frequency Distribution of Class IV-A Post Test results taught using Hand Puppet Media

The distribution of student learning outcomes in class A taught using online module media is shown in Table 4.1 as follows:

Table 2 Frequency Distribution of Class IV-A Post Tests

\begin{tabular}{|c|l|l|l|l|l|}
\hline NO & \multicolumn{1}{|c|}{ xi } & \multicolumn{1}{|c|}{ fi } & \multicolumn{1}{|c|}{ xi2 } & \multicolumn{1}{|c|}{ fixi } & \multicolumn{1}{|c|}{ fixi2 } \\
\hline 1 & 60.00 & 3 & 3600 & 180 & 10800 \\
2 & 73.33 & 9 & 5377.2889 & 659.97 & 48395.6001 \\
3 & 80.00 & 6 & 6400 & 480 & 38400 \\
4 & 86.67 & 4 & 7511,6889 & 346.68 & 30046.756 \\
5 & 96.67 & 6 & 9345.0889 & 580.02 & 56070.533 \\
\hline$\square$ & & 28 & 32234,0667 & 2246.67 & 183712.89 \\
\hline
\end{tabular}

X_—马 fixi

$\square \mathrm{fi}$

- $x \square \frac{2246,67}{28}$

X $\square 80,238214285714$

Xप80.24

Based on the calculation results, the average value of learning outcomes in class taught using hand puppet media is 80.24. Class learning outcomes data taught using hand puppet media are made in the form of a bar chart as follows: 


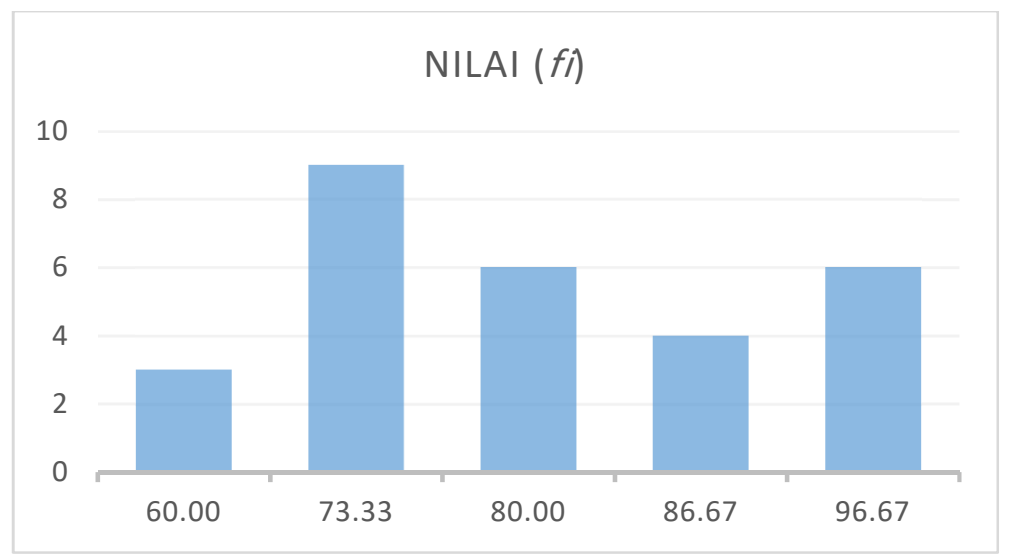

Figure 4.1 Bar Chart of Class A Post Test Value Data

Based on the bar chart image above, it explains that the horizontal axis is to represent student grades and the vertical axis is to express the frequency of the scores obtained by each student. From the diagram above, it can be explained that a value of 60.00 was obtained by 3 students, a value of 73.33 was obtained by 9 students, a value of 80.00 was obtained by 6 students, a value of 86.67 was obtained by 4 students, and a score of 96.67 was obtained by 6 students.

Data Frequency Distribution of Class B Post Test results taught by Using Conventional Learning

The distribution of data on class learning outcomes taught by conventional learning is in table 4.2 below:

Table 3 Frequency Distribution of Class IV-B Post Tests

\begin{tabular}{|c|r|r|l|l|l|}
\hline NO & xi & fi & \multicolumn{1}{|c|}{ xi2 } & \multicolumn{1}{|c|}{ fixi } & \multicolumn{1}{|c|}{ fixi2 } \\
\hline 1 & 60.00 & 7 & 3600.00 & 420 & 25200 \\
2 & 70.00 & 8 & 4900 & 560 & 39200 \\
3 & 73.33 & 6 & 5377.2889 & 439.98 & 32263.7334 \\
4 & 80.00 & 5 & 6400 & 400 & 32000 \\
5 & 90.00 & 2 & 8100 & 180 & 16200 \\
\hline$\square$ & & 28 & 28377.2889 & 1999.98 & 144863.733 \\
\hline
\end{tabular}

X_Q

- ${ }_{\text {X }}^{\frac{1999,98}{28}}$ 
X 71.4278571428571

X๐ 71.43

Based on the results of calculations, the average value of learning outcomes in classes taught by conventional learning is 71.43. The learning outcome data taught by conventional learning is made in the form of a bar chart as follows:

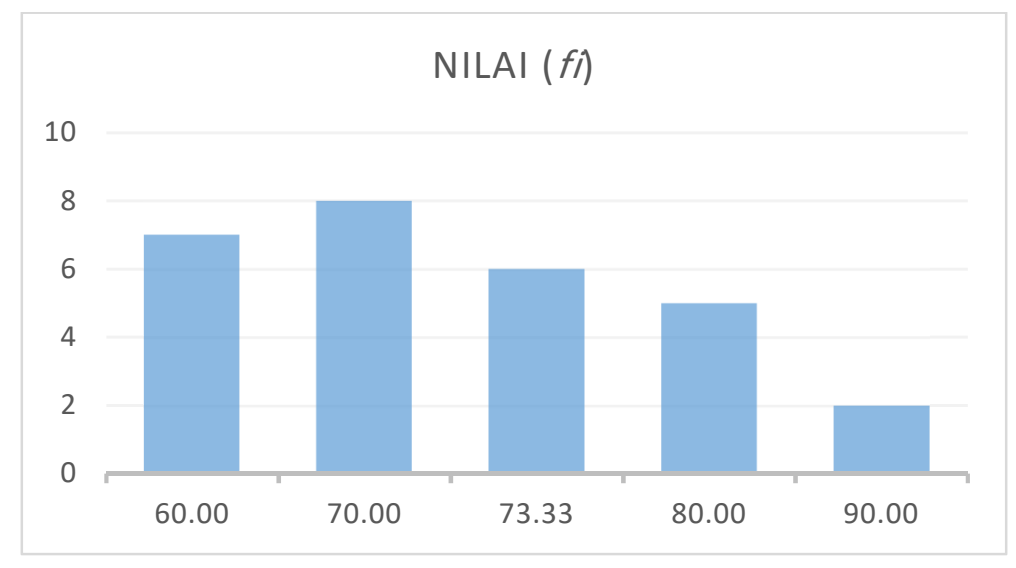

Figure 4.2 Bar Chart of Class B Post Test Value Data

Based on the bar chart image above, it explains that the horizontal axis is to represent student grades and the vertical axis represents the frequency of the scores obtained by each student. From the diagram above, it can be explained that a value of 60.00 was obtained by 7 students, a value of 70.00 was obtained by 8 students, a score of 73.33 was obtained by 6 students, a score of 80.00 was obtained by 5 students, and a value for 90.00 was obtained by 2 students.

\section{Hypothesis Testing}

Before testing the hypothesis, we first look for the data analysis requirements test, namely the normality test and the variance homogeneity test.

\section{Data Normality Test of Post Test Results}

The data normality test aims to determine whether the learning outcome data is normally distributed. The data normality test for the Post test in class A and class B is by using the Liliefors test in table 4.3 as follows:

Table 4 Post Test Data Normality Test Results

\begin{tabular}{|l|l|l|l|}
\hline Media & LO & Ltabel & Class \\
\hline Hand puppet & 0.1557 & 0.1658 & A \\
\hline Conventional Learning & 0.1629 & 0.1658 & B \\
\hline
\end{tabular}


The Effect of Using Online Module on the Learning Result of UT Students...

The normality test in class A was obtained 0.15700 .1658 because of LO LLtabel, then $\mathrm{HO}$ is accepted, so the post test data in class $\mathrm{A}$ is normally distributed. The normality test in class B obtained 0.1629 0.1658 because of LO L Ltabel, then HO is accepted, so the post test data in class B is normally distributed.

\section{Post Test Homogeneity Test}

After the normality test and the data were normally distributed, then the homogeneity test was carried out to test the variance of the population similarity. To test the homogeneity of the variance, from the two data groups the F test was used. The results of the homogeneity test are presented in table 5 below:

Table 5 Homogeneity Results of Data Post Test Results

\begin{tabular}{|l|l|l|l|l|c|}
\hline Class & $N$ & $d t$ & $s 2$ & Fcount & $\begin{array}{c}\text { Fo.050027, } \\
270\end{array}$ \\
\cline { 1 - 5 } A (Media Module online) & 28 & 27 & 127,4641 & 1.71 & 1.91 \\
\cline { 1 - 3 } $\begin{array}{l}\text { B (Learning } \\
\text { Conventional) }\end{array}$ & 28 & 27 & 74.48 & & \\
\hline
\end{tabular}

The homogeneity test of learning outcomes data in classes taught using online module media and classes taught using conventional learning was obtained Fcount 1 1.71, but not in the table then at F 0.050027 .270 interpolate and be obtained. based on criteria F. $00.050027 .270 \mathrm{Q} 1.91$ - hypothesis criteria, then Fcount QFtable $H_{0}$ accepted, meaning that the data is categorized as homogeneous.

\section{Hypothesis testing}

After performing the normality test, the homogeneity of the variance test data and the data obtained were normally distributed and the variance was homogeneous. Then the hypothesis is tested with an independent test between the two factors.

The results of independent testing between the two factors are compiled in table 6 below:

Table 6 Independent Results Between Two Factors

\begin{tabular}{|l|l|l|l|l|}
\hline Class & B & K & xhitung2 & xtabel2 \\
\hline A (Using Online Module Media) & 0.95 & 2 & 13,7447 & 5.99 \\
\hline
\end{tabular}


Kuala Ginting, Gemala Widoyarti

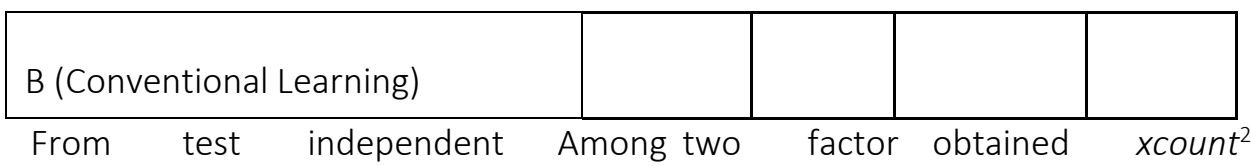

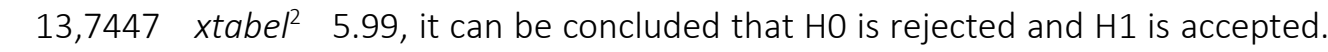
So it can be stated that there is a significant effect of using the Online Module media on the ability of UT student learning outcomes at the final exam passing level.

4. The Degree of Relationship between the Use of Online Modules and the Ability of Student Learning Outcomes

After getting the hypothesis results, the researcher then tested the degree of the relationship between the use of the online module and the learning outcomes ability. From the test of the degree of the relationship between the use of the online module and the ability to write stories, it was obtained that $\mathrm{C}=0.4439$ and $\mathrm{Cmax}$ 0.7071. From the results of these data, it is stated that the closer the price of $\mathrm{C}$ to $\mathrm{C}$ max, the greater the degree of relationship of the online module media to the students' story writing ability.

\section{Discussion of Research Results}

After the pre-test was carried out, the researcher carried out the learning which began on March 5, 2020, the researcher taught in class A using online modules and B using conventional learning. The learning on the first day of the researcher explained the story, then gave the assignment and at the end it was discussed together. On the second day, March 6, 2020, the researcher conducted learning again and repeated the material only, and at the end of the lesson the researcher gave a post test or final test to find out whether there was an effect of learning using online module media with conventional learning.

And the average value obtained from the post test results in class $A$ as the experimental class is 80.24 , while the average value of class $B$ as the control class is 71.43. From the average value it can be stated that the higher score is the grade $A$ grade using the online module media.

After that the data from the post-test results for classes $A$ and $B$ were tested using the Liliefors test, namely using the normality test and the homogeneity test of variance. After being tested for classes A and B with normal and homogeneous distributions, it was continued with hypothesis testing using an independent formula between the two factors. After the independent test between the two factors in the 
two classes is carried out, the results of xhitung2 are obtained $13,7447 \square \times$ tabel 15.99, then $\mathrm{HO}$ is rejected and $\mathrm{H} 1$ is accepted. So it can be stated that learning using online modules is more influential than conventional learning or it can be stated that there is a significant effect of using online modules on the ability of student learning outcomes in the final semester of the 2020 registration period. After getting the results of the hypothesis, the next step is to test the relationship between the use of online modules and the ability to learn outcomes. From the degree of relationship test using the online module obtained $C=0.4439$ and $C \max 00.7071$. From the results of these data, it is stated that the value the closer the price of $\mathrm{C}$ to $\mathrm{C}$ max is, the greater the degree of the relationship between the hand puppet media and the learning outcomes ability.

\section{E. Conclusion}

Based on data analysis and research hypothesis testing conducted in Class A and B semester nine UT students registration period 2020.1 it can be concluded as follows:

1. Student learning outcomes using conventional learning in final semester UT students obtained an average value of 71.43 .

2. Student learning outcomes using the online module in the final semester students obtained an average value of 80.24 .

There is a significant effect of using the online module on UT student learning outcomes at the level of passing the final exam.

\section{Bibliography}

Belawati, T. (2002). Perkembangan Pemikiran tentang Pendidikan Terbuka dan jarak jauh. Jakarta : Universitas Terbuka .

Hamalik, O. (2007). Proses Belajar mengajar. Bandung: Bumi aksara .

Haryanto. (2001). Pelayanan Modul dan Berkas registrasi kepada mahasiswa program Dd2 PGSD Beasiswa Pemda Daerah Tingkat 1 di seluruh Indonesia. Laporan Penelitian: LPPM Universitas Terbuka.

Sudjana, N. (2005). Penilaian hasil proses belajar mengajar. Bandung : PT. Remaja Rosdakarya.

Sugilar, \& Abseni. (2013). Analisis pola pemanfaatan UT. Online. Laporan Penelitian: LPPM Universitas Terbuka. 
Kuala Ginting, Gemala Widoyarti

Sugiyono. (2017). Metode Penelitian Pendidikan Pendekatan Kuantitatif, Kualitatif, dan R\&D. Bandung: Alfabeta. 